\title{
FUNGAL SPORES AND POLLEN AS POTENTIAL NUTRITIONAL ADDITIVES FOR THE CROSS SPIDER Araneus diadematus Clerck (ARANEAE, ARANEIDAE).
}

\author{
Esporas fúngicas y polen como potenciales aditivos nutricionales para la \\ araña del jardín Araneus diadematus Clerck (Araneae, Araneidae).
}

\author{
Del Fiol Federica, Tosi Solveig \& Groppali Riccardo \\ Dipartimento di Ecologia del Territorio, Università di Pavia, \\ via S. Epifanio 14, 27100, Pavia, Italy. \\ tel: +39382984870, fax:+3938234240 email: solveig.tosi@unipv.it
}

Keywords: Araneus diadematus, fungal spores, pollen, nutritional additives

Palabras clave: Araneus diadematus, esporas fúngicas, polen, aditivos nutricionales

\begin{abstract}
Prior to make a new cobweb, the Araneus diadematus Clerck cross spider eats its old web regulary everyday. In this paper we issue a quantitative and qualitative analysis of pollen grains and fungal spores present in the cob web, which might contribute to the diet of this arachnide. Cob webs were collected at the Natural Park of Ticino (Pavia, northern Italy). Fungal spores and pollen grains were taxonomically counted and identified for each sample. Quantitative analysis showed that both spores and pollen present in the cob webs exhibited some seasonal variation as regards quantity, whereas the qualitative analysis revealed that spores and pollen grains belong to 14 and 7 taxa, respectively. Alternaria, Cladosporium, Fusarum were the most frequent fungal taxa while Urticaceae, Betulaceae and Poaceae became the most representative plant families. About 5700 fungal spores and 2000 pollen grains were found to be present in the cob web of this spider everyday. Based on this information, it is possible to think that the aeroplancton stuck to the cob web can become a nutritional additive for the diet of this arachnide.
\end{abstract}

\section{INTRODUCTION}

Spiders are predators living in almost all terrestrial habitats; they usually prey on insects but other arthropods

Recibido el 3 Diciembre, 2006

Aceptado el 10 de Marzo, 2007

\section{RESUMEN}

Antes de fabricar su telaraña, la araña del jardín Araneus diadematus Clerck, regularmente, cada día se come la antigua. En este estudio aportamos un análisis cuantitativo y cualitativo de los granos de polen y esporas fúngicas retenidas en la telaraña, los cuales podrían contribuir a la dieta de este aracnido. Las telarañas fueron colectadas en el Parque Natural del Ticino (Pavia, N. Italia). Para cada muestra, las esporas fúngicas y los granos de polen fueron contabilizados e identificados taxonómi-camente. El análisis cuantitativo mostró que las esporas y el polen retenidos en las telarañas presentaron variación estacional en cantidad, mientras con el análisis cualitativo se determinó que las esporas y los granos de polen pertenecen a 14 y 7 taxa respectivamente. Alternaria, Cladosporium, Fusarium fueron los taxa fúngicos más frecuentes, mientras Urticaceae, Betulaceae y Poaceae fueron las familias de plantas más representadas. Se determinó que aproximadamente unas 5700 esporas fúngicas y 2000 granos de polen fueron retenidos en la tela de esta araña cada día. Con estos antecedentes, se puede pensar que el aeroplancton adherido a la telaraña puede constituir una aporte nutritivo en la dieta de este arácnido.

are often consumed as well. Spiders, like many other arthropods, are able to produce silk and they use it not only for making egg sacs but also for building webs in which prey can be trapped (Wise, 1993). The web works as a snare not only for arthropods but for all elements that blow in the air. Air contains aeroplankton mainly 
constituted of bacteria and suspended elements such as spores and pollen grains. The most representative genera of fungal spores in the atmosphere are usually Alternaria, Cladosporium, Penicillium, Aspergillus and Mucor (Kaarik et al., 1983). A functional orb-web, with its sticky droplets, can catch a large quantity of airborne pollen grains and fungal spores. Before building a new web, $A$. diadematus eats its old web every day (Nielsen, 1932, Breed et al., 1964) and the silk proteins are recycled in the new web (Foelix, 1982).

While spiders eat their webs, they may simultaneously ingest adhering pollen and spores which could be an additional nutrient source (Smith \& Mommsen, 1984). In this paper we provide a qualitative and quantitative analysis of airborne fungal spores and pollen grains in spider webs which may contribute to the diet of the cross spider Araneus diadematus.

\section{MATERIALS AND METHODS}

Samples of $A$. diadematus webs were collected in the Natural Park of Ticino, Pavia, Italy $\left(45^{\circ} \mathrm{N}\right.$ latitude, $8^{\circ}$ E longitude), in summer (July) 2002, autumn (September, October) 2002 and spring (May) 2003. One portion of each web was collected directly onto the slide, sticking the threads easily on it. A total of 18 different webs' samples were collected, 6 in each season.

Each web portion covers all 13.34 sq. $\mathrm{cm}$. of a slide. Slides were immediately put into sterile Petri dishes and analyzed in the laboratory.

Slides were stained with Lactophenol-acid fucsin (Carmichael, 1955) and then observed under the microscope (Axioplan, Zeiss) with a magnification of 400X. For each season, fungal spores and pollen grains were counted and taxonomically identified using an aerobiological atlas (Gregory, 1961; Bassett et al., 1978; Kaarik et al., 1983). Mitosporic fungi were identified at genus level whereas Ascomycota and Basydiomycota at phylum level. Pollen grains were identified at familia level. In order to calculate how many spores and pollen grains were stuck on a web, $25 \mathrm{~A}$. diadematus webs were randomly collected within the sampling area and measured to evaluate the web average area. To analyse the variations of pollen and spore amount in the different seasons, data were previously checked for normality and homogeneity of variance and, then, analyzed by means of ONE -Way ANOVA and TUKEY's multicomparison tests.

\section{RESULTS AND DISCUSSION}

The web average area was calculated to be 879.7 sq cm +/- 138.9. Qualitative and quantitative data on fungal spores and pollen grains for each sampling season are reported in Table 1.

Qualitative analysis identified spores and pollen grains belonging to 14 and 7 taxa respectively. In Table 1 the amounts' arithmetic means with standard deviation of all fungal and pollen taxa are also reported. The most frequent fungal taxa were Alternaria, Cladosporium, Fusarium and same member of Ascomycota and Basidiomycota; whereas the most representative pollen taxa were Urticaceae, Betulaceae and Poaceae.

Spores and pollen grains stuck on a web show a seasonal variation in their quantity. Distributions of spores and pollen grains show an opposite trend: spores are few in spring (1.530), increase in summer (5.355) and reach the top of concentration in autumn (10.460); pollens are more plentiful in spring (2.980), decrease in summer (1.900) and reach the lower amount in autumn (1.220). Based on the quantitative data more than 5.700 fungal spores and 2.000 pollen grains are calculated to be stuck on a single mean web.

Statistical data are presented in Table 2 and 3, spores show significant differences between spring and autumn and between summer and autumn; pollen grains show significant differences only between spring and autumn.

Fungal and pollen trends are correlated to the seasonal fungal and plant life cycle in the surroundings (Del Fiol, 2004). Spore fungal concentration depends on many environmental factors like temperature, humidity and wind and varies from 200 to 2.000 .000 spores per cubic meter, but the daily average quantity is $10.000-20.000$ spores (Bassett et al., 1978). Dimensions of airborne spores vary from 2,5 to 90 microns (Gregory, 1989; Kirk et al., 2001). Concentration and quality of airborne pollen grains depend on climate and vegetation in the surroundings; anemophilous plants produce most of the pollen grains. Dimensions of pollen vary from 10 to 200 microns (Erdtman, 1971).

In our data Alternaria shows a peak in summer, probably due to its association with plants that are at the maximum of their leaf development; the peak of Basidiomycota in autumn can be explained by the fact that during their life cycle fruiting bodies (mushrooms) develop in this season with the subsequent release of basidiospores into the air.

The results here presented make it clear that the diet of the cross spider could be complex in a natural environment. More than arthropods, airborne fungal spores and pollen grains and surely sporigenous bacteria (the presence of which the authors did not analyze) could be potential nutritional additives for $A$. diadematus. If it is demonstrated that the web is consumed with the aeroplancton stuck on it, this kind of food will be 
Table 1: Qualitative and quantitative data on fungal spores and pollen grains for each sampling season are reported. The numbers represent the amount arithmetic means with standard deviation of different fungal spores and pollens counted on the 6 webs. In the last column the annual mean is reported

\begin{tabular}{|c|c|c|c|c|}
\hline SPORES & May 2003 & July 2002 & Sept-Oct. 2002 & Mean \\
\hline $\begin{array}{l}\text { Alternaria } \\
\text { Cladosporium } \\
\text { Fusarium } \\
\text { Torula } \\
\text { Venturia } \\
\text { Bispora } \\
\text { Aspergillus } \\
\text { Bipolaris } \\
\text { Scopulariopsis } \\
\text { Stemphylium } \\
\text { Dendryphiella } \\
\text { Nigrospora } \\
\text { Ascomycota } \\
\text { Basidiomycota }\end{array}$ & $\begin{array}{l}76.9+/-59.2 \\
274.8+/-70.4 \\
0 \\
87.9+/-72.9 \\
43.9+/-62.8 \\
153.8+/-155.4 \\
0 \\
43.9+/-49.2 \\
0 \\
0 \\
0 \\
65.9+/-76.1 \\
780.4+/-154.2 \\
0\end{array}$ & $\begin{array}{l}1938.8+/-827.4 \\
672.6+/-137.1 \\
184.6+/-102.8 \\
290.1+/-241.7 \\
224.2+/-79.1 \\
131.9+/-95.1 \\
92.3+/-79.1 \\
131.9+/-250.3 \\
118.7+/-178.9 \\
13.2+/-26.3 \\
0 \\
0 \\
1556.3+/-538.3 \\
0\end{array}$ & $\begin{array}{l}791.3+/-1082.6 \\
1417.8+/-858.5 \\
4121.5+/-2006.2 \\
423.3+/-380.2 \\
224.2+/-255.2 \\
131.8+/-177.9 \\
39.6+/-109.1 \\
171.4+/-248.7 \\
32.9+/-87.2 \\
92.3+/-177.3 \\
16.5+/-43.6 \\
214.3+/-167.7 \\
1302.4+/-488.7 \\
1483.7+/-1473.1\end{array}$ & $\begin{array}{l}936.4 \\
789.1 \\
1435.4 \\
266.4 \\
162.7 \\
138.4 \\
44 \\
114.3 \\
50.5 \\
35.2 \\
5.5 \\
87.9 \\
1212.3 \\
494.6\end{array}$ \\
\hline Total & 1529.9 & 5354.7 & 10458.8 & 5781.1 \\
\hline \multicolumn{5}{|l|}{ POLLENS } \\
\hline $\begin{array}{l}\text { Poaceae } \\
\text { Araliaceae } \\
\text { Ulmaceae } \\
\text { Cupressaceae } \\
\text { Convolvulaceae } \\
\text { Urtcaceae } \\
\text { Betulaceae }\end{array}$ & $\begin{array}{c}0 \\
0 \\
0 \\
0 \\
0 \\
2110.2+/-983.8 \\
867.1+/-194.9\end{array}$ & $\begin{array}{l}1226.6+/-420.4 \\
118.7+/-105.5 \\
553.9+/-223.1 \\
0 \\
0 \\
0 \\
0\end{array}$ & $\begin{array}{l}975.9+/-843.9 \\
0 \\
0 \\
214.3+/-79.1 \\
26.4+/-45.9 \\
0 \\
0\end{array}$ & $\begin{array}{l}734.2 \\
39.6 \\
184.6 \\
71.4 \\
8.8 \\
703.4 \\
290.2\end{array}$ \\
\hline Total & 2980.7 & 1899.2 & 1219.9 & 2033.3 \\
\hline
\end{tabular}

considered a conspicuous part of the cross spider's diet. Fungal spores are more represented than pollen grains on the spider's orb-web, so their contribution in its diet should be higher even if the average dimensions of the larger pollen grains had to be taken into account. Smith \& Mommsen (1984), argued that the pollen grains are energetically important for the juveniles during spring when insects are rare; on the contrary they found that the energetic contribution of fungal spores to the diet of $A$. diadematus was minimal and, in some cases, deleterious; but this was deduced on the results on only one kind of

Table 2: ONE-way ANOVA comparison between the average number of spores/pollens per web counted in samples of May, July and September-October. F,test

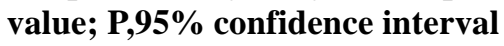

\begin{tabular}{|l|l|l|}
\hline \multicolumn{1}{|c|}{ Period } & \multicolumn{1}{c|}{ Av N. spores } & \multicolumn{1}{c|}{ Av. N pollens } \\
\hline May & $23.2 \pm 3.6$ & $46.6 \pm 16.2$ \\
\hline July & $81.2 \pm 21.1$ & $28.8 \pm 9.7$ \\
\hline Sept-Oct & $149.6 \pm 57.0$ & $17.2 \pm 9.3$ \\
\hline ANOVA & $\mathrm{F}=16.2 ; \mathrm{p}<0.05$ & $\mathrm{~F}=7.4 ; \mathrm{p}<0.05$ \\
\hline
\end{tabular}

spore (Cladosporium herbarum). C. herbarum is reported to produce endotoxins (Gorlenko, 1948); mycelial extracts were found to be toxic to chicken embryos (Diener et al., 1976). Toxic effects on warm blooded animals were recorded, too (Joffe, 1962). But fungi have different organic chemical composition and content of toxic metabolites; consequently, many species can be nutritio-nally useful and some can be deleterious.

Table 3: Tukey multicomparison test.

\begin{tabular}{|l|l|l|l|}
\hline \multicolumn{1}{|c|}{ Spores } & \multicolumn{1}{c|}{ May } & \multicolumn{1}{c|}{ July } & October \\
\hline May & & & \\
\hline July & Ns & & \\
\hline October & Sd & Sd & \\
\hline Pollens & \multicolumn{1}{|c|}{ May } & July & October \\
\hline May & & & \\
\hline July & Ns & & \\
\hline October & Sd & Ns & \\
\hline
\end{tabular}

Sd = significative differences

Ns = non significative differences 
The energetic contribution of different kinds of pollens and spores could be estimated in the future, to determine their relative importance as potential additional nutrient source for A. diadematus throughout the year.

\section{ACKNOWLEDGMENTS}

Thanks to Prof. Giuseppe Caretta (Dipartimento di Ecologia del Territorio, Sezione di Micologia, Università di Pavia, Italy) for his suggestions and comments during the preparation of the manuscript.

\section{REFERENCES}

Bassett, I.J.; Crompton C.W.; Parmelee J.A. (1978). An Atlas of Airborne Pollen Grains and Common Fungus Spores of Canada. Biosystematics Research Institute, Ottawa, Ontario.

Bera, S.K.; Trivedi, A.; Sharma, C. (2002). Trapped pollen and spores from spider webs of Lucknow environs. Current Science 83, 15801585

Breed, A.L.; Levigne V.D.; Peakall D.B.; Witt P.N. (1964). The fate of the intact orb web of the spider Araneus diadematus. Behaviour 23, $43-60$.

Carmichael, J.W. (1955). Lacto-fushin a new medium for mounting fungi. Mycologia 47: 611.

Dahl, F. (1931). Die Tierwelt Deutschlands und der angrenzenden Meeresteile. 23. Teil Spinnentiere oder Arachnoidea. VI AgelenidaeAraneidae. Fischer, Jena.

Del Fiol, F. (2004). Pollini e spore fungine su tele di Araneus diadematus (Arachnida Araneae). Degree thesis, University of Pavia, Italy.

Diener, U.L.; Vagener, R.E.; Morgan-Jones, G.; Devis, N.D. (1976). Toxigenic fungi from cotton. Phytopathology 66: 514516.

Erdtman, G. (1971). Dermatiaceous Hypomycetes. Commonwealth Mycological Instistute. Key, Surrey, England.

Foelix, R. (1982). Biology of Spiders. Oxford University Press, Oxford.
Foelix, F. (1997). Biology of Spiders. Oxford University Press, Oxford.

Gorlenko, M.V. (1948). The toxins of molds. American review of Soviet medicine 5: 163-164.

Gregory, P.H. (1961). The Microbiology of the Atmosphere. Interscience publishers, Inc. New York.

Gregory, B.M. (1989). Field observation of Gasteracantha cancriformes (Araneae, Araneidae) in a Florida mangrove stand. Journal of Arachnology 17, 119-120.

Joffe, A.Z. (1962). Biological properties of some toxic fungi isolated from overwintered cereals. Mycopathologia e Mycologia Applicata 16: 201-221.

Kaarik, A.; Keller, J.; Kiffer, E.; Perreau, J.; Reisinger, O. (1983). Atlas of Airborne Fungal Spores in Europe. Springer-Verlag, Berlin, Heidelberg, New York.

Ludy, C. (2004). Intentional pollen feeding in the garden spider Araneus diadematus. Newsletter of the British Arachnological Society $101,4-5$

Ludy, C. \& Lang, A. (2006). Bt maize pollen exposure and impact on the garden spider, Araneus diadematus. Entomologia, Experimentalis et Applicata 118, 145-156.

Mayntz, D.; Toft, S.; Vollrath, F. (2003). Effects of prey quality and availability on the life history of a trap-building predator. Oikos 101, 631-638.

Nielsen, E. (1932). Biology of Spiders. Volume1. Levin \& Munksgaard, Copenhagen.

Skow, C. D. \& Jakob, E.M. (2003). Effects of maternal body size on clutch size and egg weight in a pholcid spider (Holocnemus pluchei). Journal of Arachnology 31, 305-308.

Smith, R.B. \& Mommsen, T.P. (1984). Pollen feeding in an orbweaving spider. Science 226, 1330-1332..

Wise, D.H. (1993). Spiders in Ecological Webs. Cambridge, Massachusetts: Cambridge University Press 